\title{
Production and Evaluaton of Yoghurt Flavoured with Beetroot (Beta vulgaris L.)
}

\author{
Mbaeyi-Nwaoha, Ifeoma Elizabeth and Nwachukwu Godstar Onyinyechi \\ Department of Food Science and Technology, University of Nigeria, Nsukka, Enugu State, Nigeria
}

Received: May 31, 2012 / Published: October 20, 2012.

\begin{abstract}
Beetroot (Beta vulgaris L.) was pulped to get the juice. The juice was given heat treatment. Yoghurt was formulated and flavored with prepared beetroot (Beta vulgaris L.) juice at different concentration levels $(0,10,20,30,40$ and $50 \mathrm{~mL})$. The most preferred flavored yoghurt samples were obtained by sensory scores (color, flavor, mouth feel, aftertaste and overall acceptability). The most preferred sample was then subjected to proximate, physico-chemical, microbiological and micro-nutrient analysis. The result obtained showed that the $\mathrm{pH}$ value ranged between 6.5 and 7.8. Thus, this showed that the product was quite good. However, ash and moisture content increased with addition of the beetroot juice, while micro-nutrient, ( $\mathrm{Mg}, \mathrm{Na}, \mathrm{K}, \mathrm{Ca}$ and Vitamin $\mathrm{C}$ ) increased with the addition of the juice. There was no significant difference $(P>0.05)$ in the overall acceptability of all products. There was no coliform and mould growth in all the samples. The best concentration level in the samples was $90 \mathrm{~mL}$ of yoghurt and $10 \mathrm{~mL}$ of beetroot juice. Therefore, the beetroot flavored yoghurt could be said to be nutritious, safe and an acceptable product by the panelists.
\end{abstract}

Key words: Beetroot, yoghurt, sensory properties, micronutrients.

\section{Introduction}

Yoghurt is the most widely consumed fermented dairy dessert worldwide. Yoghurt is a fermented milk product produced by adding a starter of active yoghurt containing a mixed culture of Lactobacillus bulgaricus (or occasionally acidophilus) and Streptococcus thermophilus. These produce lactic acid during fermentation of lactose. The lactic acid lowers the $\mathrm{pH}$, makes it tart, causes the milk protein to thicken and act as a preservative since pathogenic bacteria cannot grow in acid condition. The partial digestion of the milk when these bacteria ferment milk makes yoghurt easily digestible [1]. It is consumed by people of all ages including pre-school children and expectant mothers. It is also consumed by people of variable physical status, from the youthful athlete to the old and infirmed adult. The nutritional and healthy benefits of yoghurt are

Corresponding author: Nwaoha, Ifeoma Elizabeth (nee Mbaeyi), Ph.D., research field: food and industrial microbiology. E-mail: miphie2003@yahoo.co.uk, eoma.mbaeyi-nwaoha@unn.edu.ng. numerous. It is a good source of protein, energy (calories), vitamins and minerals. As a fermented product, it may also have therapeutic value and may also result in reduced incidences of lactose intolerance. The fermentation of milk to yoghurt takes relatively short period of time, 3-4 hours, because it is done at a higher temperature $\left(42-46{ }^{\circ} \mathrm{C}\right)$ and also uses culture that have fast growth rates. In yoghurt making, the major fermentation product is lactic acid which is responsible for coagulation of the milk caseins. Other metabolites that are responsible for the yoghurt flavor are also produced during the fermentation and these include diacetyl, acetaldehyde and acetone.

Fruits are added to the fermentation media to enhance organoleptic properties. In stirred yoghurt, fruits are added post fermentation and in set yoghurt, they are added prior to the fermentation. To modify certain properties of yoghurt, various ingredients may be added for examples, to sweeten yoghurt, sucrose may be added to increase the calorie artificial sweetener such as aspartame may be added, cream 
could also be added to provide texture. The consistency and shelf stability of the yoghurt could be improved by the inclusion of stabilizers such as food starch, gelatin, locust bean gum and pectin. To improve taste and flavor, many kinds of fruit may be added such as vanilla, orange, pineapple, strawberry, raspberry, milk, cinnamon, bananas, peaches, mandarins and passion fruit. The indigenous fruit used in this study is called Beetroot (Beta vulgaris L.), had already been established as a flavoring agent or a special flavor that is generally liked by the people who have known its benefit, functions and also how it will enhance the keeping quality of yoghurt.

Beetroot, as a flavoring agent, is a member of the Chenopodiaceae family which includes silver beet, sugar beet and fodder beet [2]. They are biennials although they are usually grown as annuals and believed to have originated from Germany [3]. Beetroot produces green tops and a swollen root during growing season. It is highly productive and usually free of pests and diseases [4]. It is rich in several vitamins, hence it is an ideal vegetable for health conscious people [2]. Beetroot is usually grown for salad and extraction of sugar from roots. The ball is usually round and small with thin red-brown skin and notably sweet flavor. Red Beetroot has the peculiarity of bleeding a crimson dye called betanin [5]. Beetroot is usually cooked, blanched, steamed or boiled whole with some of greens left intact. When sliced after cooking, it has a tendency to stain other ingredients [5]. Beetroot is a crop of temperate region where cool weather and high humidity are available [6]. Its performance is better in long days having low night temperature [5].

Beetroot pigments are betalian pigment, which they replace in some organisms. They are named after the Beet family of plant (Beta) but are also found in fungi (fly-Agaric the red, spotted one). In petals, they presumably attract pollinating insect and may be present in seeds/fruits to encourage birds to eat them and so disperse the seeds. Beetroot has been selected for color because it is more attractive and also because it may be well linked to genes for flavor too. Beetroot pigment is used commercially as a food dye. It changes color when heated, so it can only be used in ice-cream, sweets, yoghurt and other confectionary, and it is a good flavoring agent, but it has no known allergic side effects [7]. Beetroot is a common salad ingredient when cooked vinegar is added to the water to lower the $\mathrm{pH}$. Beetroots are a rich source of potent antioxidants and nutrients, it can be used for blood pressure, for cardiovascular disease prevention, for healthy liver function, for cancer prevention among others [8]. Beetroot juice has been shown to lower blood pressure and thus, help prevent cardiovascular problems. Research published in the American Heart Association Journal Hypertension showed drinking $500 \mathrm{~mL}$ of beetroot juice led to a reduction in blood pressure within one hour [7].

The main aim of this research was to formulate yoghurt flavoured with Beetroot (Beta vulgaris L.) juice of different concentrations and to determine the microbial, proximate, physiochemical and micronutrient composition of the beetroot flavored yoghurt.

\section{Materials and Methods}

The materials used for the production of flavored yoghurt were beetroot, milk, starter culture (yoghurmet). Beetroot and other materials, (starter culture, skimmed milk and sugar) were purchased at Ogige main market, Nsukka, Enugu State, Nigeria.

\subsection{Sample Preparation}

A liter of yoghurt was produced by mixing $150 \mathrm{~g}$ of skimmed milk with $850 \mathrm{~mL}$ of distilled water. Pasteurization was done at the temperature of about 80-85 ${ }^{\circ} \mathrm{C}$ for $15 \mathrm{~min}$, the milk was cooled at the temperature of about $42-45{ }^{\circ} \mathrm{C}$ for $20-30 \mathrm{~min}$. The starter culture was added at this temperature and mixed thoroughly, and refrigerated immediately at the temperature of about $4{ }^{\circ} \mathrm{C}$ after $12 \mathrm{~h}$ to stop fermentation. The yoghurt sample was flavored with different concentrations of the root juice (beetroot). 
Beetroot pulp was prepared using the method of FAO [9] as shown in Fig. 1.

The total weight of beetroot ( $204 \mathrm{~g}$ ) was taken by weighing using electrical weighing balance (Digital balance, Model no. 302N, made in England). Sorting was done by manual removal of contaminated ones. The beetroot was cleaned by washing in water to remove sand, adhering dirt and extraneous material. The beetroot was cut into slices of about 2-3 mm thick, and subjected to extraction using juice extractor (Binatone, model JE-500). The beetroot pulp was sieved using a muslin cloth to obtain a clear filtered juice, then the filtered juice was pasteurized at $85{ }^{\circ} \mathrm{C}$ [10] to destroy enzymes and reduce the microbial load. About $600 \mathrm{~mL}$ of the juice was obtained using $100 \mathrm{~mL}$ of distilled water. The beetroot juice was stored in an air-tight container until used.

Yoghurt was prepared using the method of Egan [11]. Below is the flowchart of its production (Fig. 2) and the formulated yoghurt flavored with beetroot juice.

\subsection{Methods}

Moisture, ash, fat and protein contents were determined using standard AOAC [12] procedure.

Carbohydrate content was determined by difference. It was done by subtracting other food component (moisture, ash, fat and protein) obtained by analysis from 100. The difference consists almost of digestible energy providing calories from carbohydrate $[12,13]$.

Percentage carbohydrate $=$

$100-(\%$ protein $+\%$ fat $+\%$ moisture $+\%$ ash $)$.

$\mathrm{pH}$ determination:

$\mathrm{pH}$ was determined using a $\mathrm{pH}$ meter (model EAL 920). Five milliliters of the sample was measured out and homogenized in $50 \mathrm{~mL}$ of distilled water. $\mathrm{pH}$ meter was first standardized using buffer solution of $\mathrm{pH}$ 4.0-9.0, sufficient time was allowed for stabilization before reading.

Total solid determination:

This was carried in accordance with the methods described by AOAC [12]. About $10 \mathrm{~mL}$ of yoghurt

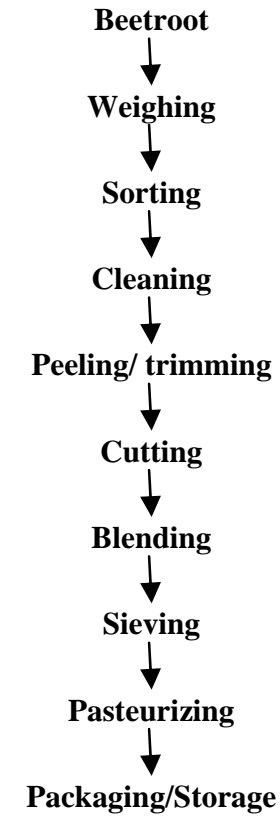

Fig. 1 Flowchart of Beetroot juice production.

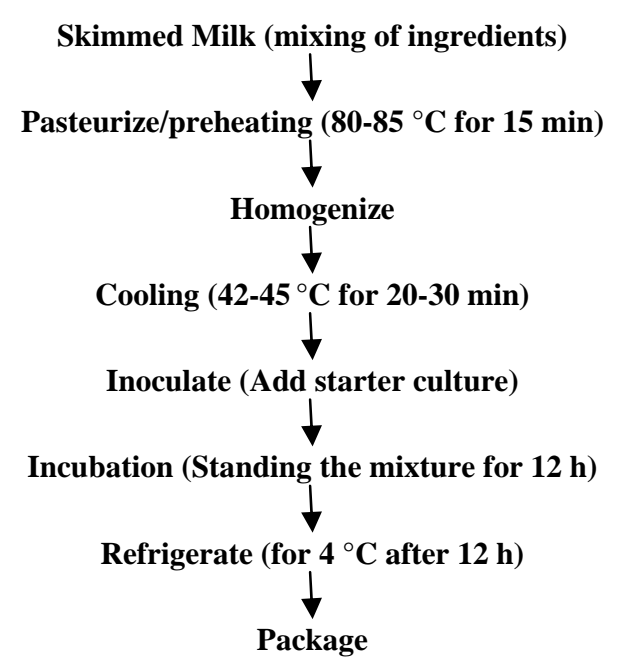

Fig. 2 Flowchart of yoghurt production.

sample was pipetted into washed, dried and weighed crucible. The dish and its contents were out in an oven and dried at the temperature of about $70{ }^{\circ} \mathrm{C}$ for $3 \mathrm{~h}$ under pressure. It was cooled in a desiccator and weight of the solid determined.

Calculation:

The percentage by mass of solid $=$

$$
\frac{\text { Weight of dryed solid }}{\text { Weight of sample } 1} \times 100
$$

Titrable acid determination:

Titrable acidity was determined according to AOAC [12]. Titrable acid determination was carried out using 
about $5 \mathrm{~mL}$ of the sample which was taken and titrated with $\quad 0.1 \quad \mathrm{~N}$ alkali $(\mathrm{NaOH})$ using $0.5 \quad \mathrm{~mL}$ phenolphthalein as indicator. Titration continued until there is a change in color to a pink end point, the titration was repeated to get average result.

Lactose determination:

The percentage of lactose was determined by means of sample calculation the total weight of fat, protein and ash was subtracted from the weight of the total solid [14].

Calculation $=$ Total solid $-(\%$ fat $+\%$ protein $+\%$ ash).

Total viable count:

The total viable count test was carried out using Prescott [15]. Using of sample and sterilized quarter strength ringer solution as diluents, $1 \mathrm{~mL}$ of the sample and $9 \mathrm{~mL}$ ringer solution was made serial dilutions. The diluted sample was pipetted into a marked Petri dish, swirled to mix and incubated at the temperature of about $37{ }^{\circ} \mathrm{C}$ for $24 \mathrm{~h}$. After incubation, the number of colonies was counted and represented as colony forming unit per milliliter.

Total viable count $(\mathrm{cfu} / \mathrm{mL})=$

number of colony $\times$ dilution factor

Coliform determination:

Prescott [15] was used in this determination. About $10 \mathrm{~mL}$ of prepared Mac Conkey agar was added into the Petri dish containing $1 \mathrm{~mL}$ of the sample. After inoculation, it was incubated at temperature of about $37{ }^{\circ} \mathrm{C}$ for $24 \mathrm{~h}$, after incubation, the number of colony was counted and represented as colony forming unit [15].

Mould count determination:

Mould count determination was done according to Prescott [15]. The agar used was Sabouraud dextrose agar. About 12-15 mL of Sabouraud dextrose agar was added to the $1 \mathrm{~mL}$ of sample in the Petri dish. It was thoroughly mixed and allowed to set before incubating at the temperature of $37^{\circ} \mathrm{C}$ for $48 \mathrm{~h}$. After incubation, the number of colonies was counted and represented as colony forming unit per gram.
Lactic acid bacteria determination:

This was done by carrying out a serial dilution on the sample in duplicate. Then using the pour plate method, the sample and MRS agar were put in the Petri dish and incubated under anaerobic condition the temperature of $37^{\circ} \mathrm{C}$ for $48 \mathrm{~h}$.

Vitamin $\mathrm{C}$ determination:

According to Pearson [16] method, vitamin C determination, about $5 \mathrm{~g}$ of the sample and $2.5 \mathrm{~mL}$ of $20 \%$ metaphosphoric acid used as a stabilizing agent and diluted with distilled water was weighed into a $100 \mathrm{~mL}$ volumetric flask, $10 \mathrm{~mL}$ of the solution and 2.5 $\mathrm{mL}$ of acetone was added. The absorbance reading at $264 \mathrm{~nm}$ wavelength, using UV spectrophotometer gives the vitamin $\mathrm{C}$ content.

Calcium determination:

According to Pearson [16] method, about $10 \mathrm{~mL}$ of the sample was pipetted into $250 \mathrm{~mL}$ conical flask and $25 \mathrm{~mL}$ potassium hydroxide $(\mathrm{KOH})$ and a pinch of calcine indicator was also added and titrated against ethylene diamine tetra-acetate (EDTA) solution to the end point. The volume of EDTA is the equivalent volume of calcium in the sample.

Calculation: Percent calcium $=$ Volume of EDTA $\times$ atomic weight of calcium $\times 100 \times \mathrm{DF}$ $1000 \times$ weight of sample used $\times 10$

$\mathrm{DF}=$ dilution factor.

Potassium determination:

This was carried out according to method of Kirk and Sawyer [17]. About $5 \mathrm{~mL}$ of the sample was wet ash and transferred into a $400 \mathrm{~mL}$ beaker. Using $100 \mathrm{~mL}$ water, $10 \mathrm{~mL}$ concentrated hydrochloric acid was added and set to boil for several minutes, after boiling it was allowed to cool and then diluted with water to $500 \mathrm{~mL}$, filtered and diluted again to a final concentration of approximately $15 \mathrm{mg} / \mathrm{L} \mathrm{K}_{2} \mathrm{O}$. Series of solution from the freshly prepared standard dilute potassium solution containing 10,12, 1416 , and 20 $\mathrm{mg} / \mathrm{L} \mathrm{K}_{2} \mathrm{O}$ were prepared, using a filter to give a spectral range of 766-770 nm. The sensitivity of the flame photometer was set so that the full deflection was 
equivalent to $20 \mathrm{mg} / \mathrm{L}$. Each standard solution was sprayed at least three times, checking the sensitivity between each reading against the $20 \mathrm{mg} / \mathrm{L}$ solution.

Sodium determination:

Sodium determination was performed using procedure described by Kirk [17]. About $10 \mathrm{~mL}$ of sample was wet ash followed by addition of water and $5 \mathrm{~mL}$ concentrated nitric acid, stirred and transferred to $100 \mathrm{~mL}$ volumetric flask with water and made up to the mark. The flame photometer was set up so that the scale reads zero with distilled water and 100 divisions when standard dilute sodium was sprayed. The sample solution was sprayed (suitably diluted to give a reading within the 0-100 range) and the sodium was calculated by simple proportion.

Magnesium determination:

Magnesium was determined by method according to Onwuka [13]. About $1.0 \mathrm{~g}$ of magnesium ribbon was accurately weighed and dissolved in $10 \mathrm{~mL}$ of concentrated hydrochloric acid $(\mathrm{HCl})$; the solution was boiled and evaporated to dryness on a water bath. De-ionized water was added and the solutions were transferred into a $100 \mathrm{~mL}$ volumetric flask and made up to the mark with de-ionized. From the stock, solution of concentrations $0.0,0.5,1.0$ and $1.5 \mathrm{ppm}$ was prepared to each of the magnesium solution strontium chloride solutions, was added such that there was $1,500 \mathrm{mg}$ of strontium ion in the final solution.

Sensory evaluation:

The best product was determined through sensory evaluation. This was done using 20-man semi-trained panelist from the Department of Food Science and Technology, University of Nigeria, Nsukka. The panelists were instructed to indicate their preferences for each of the samples. A nine point hedonic scale where nine was the highest score and one was the lowest score for each attribute such as color, flavor, mouth feel, aftertaste and overall acceptability was used to evaluate the product and also the interpretation of the consumer responses with respect to acceptance of the product.

\subsection{Data Analysis}

The sensory evaluation were subjected to one-way analysis of variances, the means were separated using Duncan multiple Range test and least significant difference at significant level of $P>0.05$ using SPSS version 17 computer statistical package. Microbial analysis will be subjected two-way analysis of variance.

\section{Results and Discussion}

\subsection{Microbial Content of Beetroot Flavoured Yoghurt}

In the microbial analysis carried out on the formulated products, there was coliform growth observed in sample $\mathrm{G}_{5}$. This means that there were faecal contamination in the sample and this could have been due to the environment and water used during processing, however, decrease in the activity of the lactic acid bacteria caused an increase in the $\mathrm{pH}$. Total viable count ranged from $6.4 \times 10^{3} \mathrm{cfu} / \mathrm{mL}$. This count could be responsible by the organisms that makes up the starter culture used for the fermentation of the milk (Streptococcus spp. and Lactobacillus spp.). This could be compared with the report of other researchers that the bacteria that make up the starter culture used for the fermentation could give a count of $10^{8}$ per gram of yoghurt. Lactic acid bacteria count is ranged from $1.5 \times 10-4.9 \times 10^{2} \mathrm{cfu} / \mathrm{mL}$. This could be compared with the values of Oberman and Libudzisz [18] which ranged between 200-1,000 million per mL of yoghurt. In Table 1 below, it is observed that increase in lactic acid bacteria count caused a decrease in total viable count. Mould growth occurred in the sample that contained no beetroot juice. According to Adams and Moss [19], satisfactory yoghurt should contain $\left(>10^{8}\right.$ $\mathrm{cfu} / \mathrm{g}$ of the starter culture $<1$ coliform $/ \mathrm{g}<1$ mould $\mathrm{g}^{-1}$ and $<0$ yeast $\mathrm{g}^{-1}$ ) of yoghurt.

\subsection{Micronutrient Content of Beetroot Flavoured Yoghurt}

From Table 2 below, vitamin $\mathrm{C}$ content is ranged from $6.50-9.50 \mathrm{mg} / \mathrm{mL}$. The result showed that there 
Table 1 Total viable, coliform, mould and Lactic acid bacteria (LAB) count of the beetroot flavoured yoghurt.

\begin{tabular}{lllll}
\hline Samples & TVC & Coliforms & Mould count & LAB \\
\hline $\mathrm{G}_{0}$ & $1.5 \times 10^{4}$ & - & $8.0 \times 10$ & $4.9 \times 10^{2}$ \\
$\mathrm{G}_{1}$ & $3.1 \times 10^{3}$ & - & - & $3.8 \times 10^{2}$ \\
$\mathrm{G}_{2}$ & $1.3 \times 10^{4}$ & - & - & $4.4 \times 10^{2}$ \\
$\mathrm{G}_{3}$ & $1.6 \times 10^{4}$ & - & - & $3.4 \times 10^{2}$ \\
$\mathrm{G}_{4}$ & $6.4 \times 10^{3}$ & - & - & $4.7 \times 10^{2}$ \\
$\mathrm{G}_{5}$ & $9.8 \times 10^{3}$ & $1.0 \times 10$ & - & $2.5 \times 10^{2}$ \\
$\mathrm{G}_{6}$ & $1.04 \times 10^{4}$ & - & - & $1.5 \times 10^{2}$ \\
$\mathrm{G}_{7}$ & $1.76 \times 10^{4}$ & - & - & $1.2 \times 10^{3}$ \\
$\mathrm{G}_{8}$ & $1.89 \times 10^{4}$ & - & - & $3.3 \times 10^{2}$ \\
\hline
\end{tabular}

Values are mean \pm standard deviation of duplicate determinations;

Key: - $\rightarrow$ No growth; $\mathrm{G}_{0}=100 \mathrm{~mL}$ of yoghurt; $\mathrm{G}_{1}=90 \mathrm{~mL}$ of yoghurt $+10 \mathrm{~mL}$ of beetroot; $\mathrm{G}_{2}=80 \mathrm{~mL}$ of yoghurt $+20 \mathrm{~mL}$ of beetroot; $\mathrm{G}_{3}=70 \mathrm{~mL}$ of yoghurt $+30 \mathrm{~mL}$ of beetroot; $\mathrm{G}_{4}=60 \mathrm{~mL}$ of yoghurt $+40 \mathrm{~mL}$ of beetroot; $\mathrm{G}_{5}=50 \mathrm{~mL}$ of yoghurt $+50 \mathrm{~mL}$ of beetroot.

Table 2 Selected minerals and vitamin composition of beetroot flavoured yoghurt.

\begin{tabular}{llllll}
\hline \multirow{2}{*}{ Samples } & \multicolumn{5}{l}{ Vitamin $(\mathrm{mg} / \mathrm{mL})$} \\
\cline { 2 - 6 } & Vit. C & $\mathrm{Mg}$ & $\mathrm{Ca}$ & $\mathrm{Na}$ & $\mathrm{K}$ \\
\hline $\mathrm{G}_{0}$ & $7.15 \pm 0.07$ & $0.20 \pm 0.00$ & $77.0 \pm 0.28$ & $1.0 \pm 1.12$ & $14.0 \pm 0.07$ \\
$\mathrm{G}_{1}$ & $9.10 \pm 0.00$ & $4.20 \pm 2.26$ & $61.0 \pm 0.00$ & $1.5 \pm 0.07$ & $14.0 \pm 0.07$ \\
$\mathrm{G}_{2}$ & $7.70 \pm 0.14$ & $0.20 \pm 0.00$ & $69.0 \pm 0.07$ & $1.7 \pm 0.07$ & $13.0 \pm 0.07$ \\
$\mathrm{G}_{3}$ & $8.25 \pm 0.07$ & $0.45 \pm 0.00$ & $63.0 \pm 0.07$ & $1.6 \pm 0.14$ & $14.0 \pm 0.07$ \\
$\mathrm{G}_{4}$ & $6.50 \pm 0.14$ & $2.75 \pm 0.07$ & $87.0 \pm 0.07$ & $1.5 \pm 0.14$ & $16.0 \pm 0.07$ \\
$\mathrm{G}_{5}$ & $11.50 \pm 0.42$ & $0.40 \pm 0.00$ & $63.0 \pm 0.07$ & $1.6 \pm 0.14$ & $15.0 \pm 0.07$ \\
$\mathrm{G}_{6}$ & $7.90 \pm 0.00$ & $3.15 \pm 0.00$ & $52.0 \pm 0.07$ & $1.3 \pm 0.07$ & $14.0 \pm 0.07$ \\
$\mathrm{G}_{7}$ & $7.70 \pm 0.14$ & $0.47 \pm 0.01$ & $33.0 \pm 0.00$ & $1.2 \pm 0.07$ & $14.0 \pm 0.07$ \\
$\mathrm{G}_{8}$ & $8.18 \pm 0.59$ & $0.17 \pm 0.00$ & $63.0 \pm 0.07$ & $1.6 \pm 0.14$ & $15.0 \pm 0.07$ \\
\hline $\mathrm{Va}$ & & &
\end{tabular}

Values are means \pm standard deviation of duplicate determinations;

KEY: $\mathrm{G}_{0}=100 \mathrm{~mL}$ of yoghurt; $\mathrm{G}_{1}=90 \mathrm{~mL}$ of yoghurt $+10 \mathrm{~mL}$ of beetroot; $\mathrm{G}_{2}=80 \mathrm{~mL}$ of yoghurt $+20 \mathrm{~mL}$ of beetroot;

$\mathrm{G}_{3}=70 \mathrm{~mL}$ of yoghurt $+30 \mathrm{~mL}$ of beetroot; $\mathrm{G}_{4}=60 \mathrm{~mL}$ of yoghurt $+40 \mathrm{~mL}$ of beetroot; $\mathrm{G}_{5}=50 \mathrm{~mL}$ of yoghurt $+50 \mathrm{~mL}$ of beetroot.

was an increase in vitamin $\mathrm{C}$ content with the increased concentration of the beetroot juice as seen in sample $\mathrm{G}_{5}$. Michael [20] stated that treatments reduce the amount of vitamin $\mathrm{C}$ in foods. Magnesium $(\mathrm{Mg})$ content is ranged from 0.15 to $4.75 \mathrm{mg} / 100 \mathrm{~mL}$. Sample $\mathrm{G}_{4}$ has the highest amount of $\mathrm{Mg}$ content. Magnesium increased with decrease in concentration of the beetroot juice content of the product. Calcium has the highest content ranged from 33-87 mg/100 mL. McCance and Widdowson [21] reported calcium value in yoghurt to be $120 \mathrm{mg} / 100 \mathrm{~mL}$. The values of calcium obtained in the beetroot flavoured yoghurt were less compared with Hiroya [22]. This may probably be due to the addition of the juice. In Sodium $(\mathrm{Na})$, sodium content is ranged from 1.0 to $1.7 \mathrm{mg} / 100$ $\mathrm{mL}$. Sodium content increased with decrease in the concentration of the beetroot juice, as seen in sample $\mathrm{G}_{2}$. Potassium increased in the sample with high concentration of beetroot juice. For potassium (K), sample $\mathrm{G}_{4}$ has the highest Potassium content.

\subsection{Physiochemical Composition of Beetroot Flavoured Yoghurt}

Table 3 shows the range of total solid, $\mathrm{pH}$, titrable acidity and lactose. Total solids increased with increase concentration of the beetroot juice flavour in yoghurt. Furthermore, moisture content in the table decreased with increase total solids. For example, sample $\mathrm{G}_{5}$ has the lowest moisture content and the highest total solid content. Lactose content increased with increase in beetroot juice content in yoghurt, and this could be compared with Anyanwu [23]. The $\mathrm{pH}$ ranged between 
Table 3 Physicochemical composition of the beetroot flavoured yoghurt.

\begin{tabular}{lllll}
\hline Samples & Total solids (\%) & $\mathrm{pH}$ value & Titrable acidity & Lactose $(\%)$ \\
\hline $\mathrm{G}_{0}$ & $17.03 \pm 0.9$ & $7.8 \pm 0.7$ & $0.0 \pm 0.0$ & $10.00 \pm 0.6$ \\
$\mathrm{G}_{1}$ & $15.03 \pm 0.3$ & $6.8 \pm 0.7$ & $4.2 \pm 0.7$ & $15.55 \pm 0.6$ \\
$\mathrm{G}_{2}$ & $13.06 \pm 0.4$ & $7.6 \pm 0.7$ & $1.9 \pm 0.7$ & $17.22 \pm 0.59$ \\
$\mathrm{G}_{3}$ & $15.06 \pm 0.2$ & $6.8 \pm 0.1$ & $3.2 \pm 1.4$ & $18.26 \pm 0.47$ \\
$\mathrm{G}_{4}$ & $15.08 \pm 0.28$ & $6.8 \pm 0.7$ & $3.7 \pm 0.9$ & $20.07 \pm 0.8$ \\
$\mathrm{G}_{5}$ & $21.04 \pm 0.32$ & $9.8 \pm 0.0$ & $7.2 \pm 1.4$ & $25.65 \pm 0.8$ \\
$\mathrm{G}_{6}$ & $17.01 \pm 0.42$ & $6.5 \pm 0.7$ & $0.0 \pm 0.0$ & $15.57 \pm 0.6$ \\
$\mathrm{G}_{7}$ & $15.03 \pm 0.32$ & $6.6 \pm 0.7$ & $1.9 \pm 0.7$ & $16.20 \pm 0.58$ \\
$\mathrm{G}_{8}$ & $16.04 \pm 0.32$ & $7.8 \pm 0.7$ & $3.2 \pm 1.4$ & $18.20 \pm 0.45$ \\
\hline
\end{tabular}

Values are mean \pm standard deviation of duplicate determinations;

KEYS: $\mathrm{G}_{0}=100 \mathrm{~mL}$ of yoghurt; $\mathrm{G}_{1}=90 \mathrm{~mL}$ of yoghurt $+10 \mathrm{~mL}$ of beetroot; $\mathrm{G}_{2}=80 \mathrm{~mL}$ of yoghurt $+20 \mathrm{~mL}$ of beetroot; $\mathrm{G}_{3}=70 \mathrm{~mL}$ of yoghurt $+30 \mathrm{~mL}$ of beetroot; $\mathrm{G}_{4}=60 \mathrm{~mL}$ of yoghurt $+40 \mathrm{~mL}$ of beetroot; $\mathrm{G}_{5}=50 \mathrm{~mL}$ of yoghurt $+50 \mathrm{~mL}$ of beetroot.

6.5-7.8, while titrable acidity ranged between 0.0-7.2 on Table 3 . The $\mathrm{pH}$ range was higher when compared with brands of commercial yoghurt which ranged between 4.0-4.45 reported by Orakwue [24]. This could be due to acidity impacted by beetroot juice [22]. There were no titrable acidity content in samples $\left(\mathrm{G}_{0}\right.$ and $\mathrm{G}_{6}$ ) this could be as the result of the fact that sample $\mathrm{G}_{0}$ was the control and it contained no beetroot juice, while sample $\mathrm{G}_{6}$ contained no beetroot juice also and it was thermized. Titrable acidity decreased with increase in $\mathrm{pH}$ as seen in Table 3. The $\mathrm{pH}$ of sample $\mathrm{G}_{4}$ was 7.8 while the titrable acidity of sample $\mathrm{G}_{4}$ was 0.0 . However, the $\mathrm{pH}$ decreased with increase in total solid in samples and with increase of the beetroot juice content. This could be compared with the report of Anyanwu [25].

\subsection{Proximate Composition of Beetroot Flavoured Yoghurt}

Table 4 showed that the moisture content ranged between $60.09 \%-90.08 \%$. Sample $\mathrm{G}_{5}$ had the lowest moisture content while sample $\mathrm{G}_{8}$ had the highest moisture content. This showed that moisture increased with decrease in the concentration of the juice added. Hiroya [22] reported that the moisture content of skimmed sweet yoghurt is $80 \%$ and this could be compared with $G_{1}$. The crude protein ranged from $2.15 \%-9.25 \%$ with sample $\mathrm{G}_{0}$ having the highest value and sample $\mathrm{G}_{5}$ having the lowest value of crude protein. This showed that increase in concentration of the beetroot juice in the product reduced the protein content. Oberman [18] reported protein content of yoghurt to be ranged between $4.6 \%$. The values obtained below were more than these ranges probably because of the milk used. Sample $\mathrm{G}_{3}$ was almost close to the range reported by Oberman [18]. The fat content obtained in the Table 4 below was low compared to the brands of commercial yoghurt reported by Orakwue [24], whose fat content ranged from 2.6\%-3.24\%. Sample $\mathrm{G}_{0}$ had the highest fat content while sample $\mathrm{G}_{5}$ had the lowest fat content. Yoghurt flavoured with sweetened juice reduced fat level.

Ash content ranged from $0.94 \%-1.49 \%$ and this could be compared with the range given by Mbaeyi [26] as $0.49 \%-0.98 \%$. The ash content could have been enhanced by the added juice. Carbohydrate content ranged from $22.22 \%-10.15 \%$. The concentration of carbohydrate content increased with decreased concentration of the juice in the product.

\subsection{Sensory Analysis}

From the sensory scores on Tables 5, 6, it showed that there were no significant differences $(P>0.05)$ between the samples and the control. Therefore the samples that were used for analysis were selected randomly from the sensory evaluation result which is 
Table 4 Proximate composition (\%) of the beetroot flavoured yoghurt.

\begin{tabular}{|c|c|c|c|c|c|c|}
\hline Samples & Moisture content & Crude protein & Fat content & Ash content & Carbohydrate & Fibre content \\
\hline$\overline{\mathrm{G}_{0}}$ & $78.22 \pm 0.7$ & $9.25 \pm 0.05$ & $1.56 \pm 0.04$ & $0.94 \pm 0.05$ & $10.15 \pm 0.60$ & ND \\
\hline $\mathrm{G}_{1}$ & $80.92 \pm 0.1$ & $9.22 \pm 0.05$ & $1.45 \pm 0.04$ & $0.98 \pm 0.05$ & $12.03 \pm 0.60$ & ND \\
\hline $\mathrm{G}_{2}$ & $87.09 \pm 0.7$ & $6.47 \pm 0.05$ & $1.36 \pm 0.03$ & $0.98 \pm 0.05$ & $18.34 \pm 0.71$ & ND \\
\hline $\mathrm{G}_{3}$ & $89.05 \pm 0.7$ & $3.35 \pm 0.04$ & $1.24 \pm 0.04$ & $0.98 \pm 0.04$ & $18.37 \pm 0.75$ & ND \\
\hline $\mathrm{G}_{4}$ & $88.22 \pm 0.1$ & $2.85 \pm 0.04$ & $1.26 \pm 0.03$ & $0.98 \pm 0.05$ & $22.22 \pm 0.74$ & ND \\
\hline $\mathrm{G}_{5}$ & $60.09 \pm 0.4$ & $2.15 \pm 0.04$ & $0.16 \pm 0.04$ & $0.98 \pm 0.04$ & $22.06 \pm 0.65$ & ND \\
\hline $\mathrm{G}_{6}$ & $78.20 \pm 0.5$ & $9.23 \pm 0.05$ & $1.53 \pm 0.04$ & $1.04 \pm 0.05$ & $11.17 \pm 0.80$ & ND \\
\hline $\mathrm{G}_{7}$ & $81.89 \pm 0.9$ & $9.20 \pm 0.05$ & $1.40 \pm 0.03$ & $1.47 \pm 0.05$ & $13.05 \pm 0.80$ & ND \\
\hline $\mathrm{G}_{8}$ & $90.08 \pm 1.6$ & $6.45 \pm 0.05$ & $1.28 \pm 0.03$ & $1.49 \pm 0.05$ & $18.36 \pm 0.75$ & ND \\
\hline
\end{tabular}

Values are mean \pm standard deviation of duplicate determinations KEY: $\mathrm{G}_{0}=100 \mathrm{~mL}$ of yoghurt; $\mathrm{G}_{1}=90 \mathrm{~mL}$ of yoghurt $+10 \mathrm{~mL} 0 \mathrm{f}$ beetroot; $\mathrm{G}_{2}=80 \mathrm{~mL}$ of yoghurt $+20 \mathrm{~mL}$ of beetroot; $\mathrm{G}_{3}=70 \mathrm{~mL}$ of yoghurt $+30 \mathrm{~mL}$ of beetroot; $\mathrm{G}_{4}=60 \mathrm{~mL}$ of yoghurt $+40 \mathrm{~mL}$ of beetroot; $\mathrm{G}_{5}=50 \mathrm{~mL}$ of yoghurt $+50 \mathrm{~mL}$ of beetroot $\mathrm{ND}=$ Not detected.

Table 5 Sensory scores of beetroot flavoured yoghurt.

\begin{tabular}{|c|c|c|c|c|c|c|}
\hline Sample Parameter & Color & Flavor & Mouthfeel & Taste & Aftertaste & Overall acceptability \\
\hline$\overline{\mathrm{G}_{0}}$ & $8.75 \pm 0.44^{\mathrm{a}}$ & $7.45 \pm 1.19^{\mathrm{dd}}$ & $7.80 \pm 0.94^{\mathrm{c}}$ & $7.40 \pm 1.27^{\mathrm{c}}$ & $7.35 \pm 1.18^{\mathrm{c}}$ & $7.85 \pm 1.26^{\mathrm{d}}$ \\
\hline $\mathrm{G}_{1}$ & $7.65 \pm 1.66 \mathrm{~d}^{\mathrm{e}}$ & $7.45 \pm 1.84^{\mathrm{dd}}$ & $6.60 \pm 1.31^{\mathrm{bc}}$ & $6.45 \pm 1.74^{\mathrm{bc}}$ & $6.25 \pm 1.74^{\mathrm{ab}}$ & $6.25 \pm 2.07^{\mathrm{c}}$ \\
\hline $\mathrm{G}_{2}$ & $6.60 \pm 1.69^{\mathrm{cd}}$ & $6.45 \pm 1.76^{\mathrm{cd}}$ & $5.55 \pm 2.23^{\mathrm{ab}}$ & $5.10 \pm 2.23^{\mathrm{ab}}$ & $5.60 \pm 2.01^{\mathrm{ab}}$ & $5.85 \pm 1.75^{\mathrm{bc}}$ \\
\hline $\mathrm{G}_{3}$ & $5.75 \pm 1.74^{b c}$ & $6.00 \pm 1.80^{\mathrm{bc}}$ & $5.30 \pm 2.17^{\mathrm{a}}$ & $4.39 \pm 2.51^{\mathrm{a}}$ & $4.80 \pm 2.01^{\mathrm{aa}}$ & $5.00 \pm 2.10^{\mathrm{abc}}$ \\
\hline $\mathrm{G}_{4}$ & $4.65 \pm 2.32^{\mathrm{ab}}$ & $4.90 \pm 2.38^{\mathrm{ab}}$ & $5.30 \pm 2.17^{\mathrm{a}}$ & $4.35 \pm 2.51^{\mathrm{a}}$ & $4.25 \pm 2.59^{\mathrm{a}}$ & $4.05 \pm 2.68^{\mathrm{a}}$ \\
\hline $\mathrm{G}_{5}$ & $4.30 \pm 2.73^{\mathrm{a}}$ & $4.80 \pm 2.52^{\mathrm{ab}}$ & $5.05 \pm 2.21^{\mathrm{a}}$ & $4.70 \pm 2.31^{\mathrm{a}}$ & $4.80 \pm 2.35^{\mathrm{aa}}$ & $4.55 \pm 2.62^{\mathrm{ab}}$ \\
\hline
\end{tabular}

Values are means \pm standard deviation of duplicate determinations;

Key: $\mathrm{G}_{0}=100 \mathrm{~mL}$ of yoghurt; $\mathrm{G}_{1}=90 \mathrm{~mL}$ of yoghurt $+10 \mathrm{mls}$ 0f beetroot; $\mathrm{G}_{2}=80 \mathrm{~mL}$ of yoghurt $+20 \mathrm{~mL}$ of beetroot; $\mathrm{G}_{3}=70 \mathrm{~mL}$ of yoghurt $+30 \mathrm{~mL}$.

Table 6 Sensory scores of Thermized yoghurt flavoured with different concentration of beetroot juice.

\begin{tabular}{lllllll}
\hline Sample Parameter & Color & Flavor & Mouthfeel & Taste & Aftertaste & Overall acceptability \\
\hline $\mathrm{G}_{0}$ & $8.25 \pm 0.1^{\mathrm{C}}$ & $6.65 \pm 1.87^{\mathrm{b}}$ & $6.75 \pm 1.26^{\mathrm{b}}$ & $7.15 \pm 1.26^{\mathrm{c}}$ & $5.65 \pm 2.41^{\mathrm{a}}$ & $6.70 \pm 2.12^{\mathrm{a}}$ \\
$\mathrm{G}_{1}$ & $7.65 \pm 0.87^{\mathrm{C}}$ & $6.50 \pm 2.009^{\mathrm{ab}}$ & $6.60 \pm 1.93^{\mathrm{ab}}$ & $6.60 \pm 1.81^{\mathrm{bc}}$ & $5.65 \pm 2.23^{\mathrm{a}}$ & $6.65 \pm 1.95^{\mathrm{a}}$ \\
$\mathrm{G}_{2}$ & $6.60 \pm 1.39^{\mathrm{b}}$ & $6.25 \pm 1.74^{\mathrm{ab}}$ & $5.85 \pm 1.84^{\mathrm{ab}}$ & $6.00 \pm 1.91^{\mathrm{bc}}$ & $5.85 \pm 2.13^{\mathrm{a}}$ & $6.30 \pm 1.78^{\mathrm{a}}$ \\
$\mathrm{G}_{3}$ & $5.75 \pm 1.74^{\mathrm{ab}}$ & $5.50 \pm 1.63^{\mathrm{ab}}$ & $5.70 \pm 1.71^{\mathrm{ab}}$ & $5.35 \pm 1.87^{\mathrm{ab}}$ & $5.25 \pm 1.88^{\mathrm{a}}$ & $6.05 \pm 1.70^{\mathrm{a}}$ \\
$\mathrm{G}_{4}$ & $5.35 \pm 1.81^{\mathrm{a}}$ & $5.85 \pm 1.81^{\mathrm{ab}}$ & $5.35 \pm 1.95^{\mathrm{a}}$ & $5.35 \pm 2.00^{\mathrm{ab}}$ & $5.60 \pm 2.11^{\mathrm{a}}$ & $5.90 \pm 1.74^{\mathrm{a}}$ \\
$\mathrm{G}_{5}$ & $5.25 \pm 2.31^{\mathrm{a}}$ & $5.15 \pm 2.23^{\mathrm{a}}$ & $5.30 \pm 1.80^{\mathrm{a}}$ & $4.65 \pm 2.08^{\mathrm{a}}$ & $5.70 \pm 1.41^{\mathrm{a}}$ & $6.16 \pm 1.95^{\mathrm{a}}$ \\
\hline
\end{tabular}

Values are means \pm standard deviation of duplicate determinations

Key: $\mathrm{G}_{0}=100 \mathrm{~mL}$ yoghurt; $\mathrm{G}_{1}=90 \mathrm{~mL}$ of yoghurt $+10 \mathrm{~mL}$ of beetroot; $\mathrm{G}_{2}=80 \mathrm{~mL}$ of yoghurt $+20 \mathrm{~mL}$ of beetroot; $\mathrm{G}_{3}=70 \mathrm{~mL}$ of yoghurt $+30 \mathrm{~mL}$ of beetroot; $\mathrm{G}_{4}=60 \mathrm{~mL}$ of yoghurt $+40 \mathrm{~mL}$ of beetroot; $\mathrm{G}_{5}=50 \mathrm{~mL}$ of yoghurt $+50 \mathrm{~mL}$ of beetroot.

samples $\left(\mathrm{G}_{0}-\mathrm{G}_{5}\right)$. From the Table 5, colour and acceptance decreased with increase in the proportion of the beetroot juice. This may be as the result of the red colour of beetroot juice. Flavouring the yoghurt with different concentration of beetroot juice improved the flavour, colour, taste, mouthfeel, aftertaste and the overall acceptability of the products.
Table 6 below shows the effect of thermization on the formulated yoghurt flavoured with different concentration of beetroot juice. It is observed in the table below that samples $\mathrm{G}_{0}, \mathrm{G}_{1}$ and $\mathrm{G}_{3}$ were the most preferred. This may probably be due to their colour was not affected by the effect of thermization. There were no significant differences $(P>0.05)$ between the 
samples $\left(G_{1}\right.$ and $\left.G_{2}\right)$ in terms of the flavour, aftertaste and overall acceptability which means they were all preferred. Similarly among the 6 samples, colour and mouth feel were the most preferred in sample $\mathrm{G}_{0}$. This was probably due to the absence of beetroot juice in it.

\section{Conclusions}

The result of this study showed that addition of beetroot juice to yoghurt as flavouring agent improved the physicochemical, colour and sensory properties of yoghurt, especially when added in a little quantity $(5-10 \mathrm{~mL})$. The addition of beetroot juice in yoghurt improved the acceptability as seen in the sensory scores obtained. Vitamin $\mathrm{C}$ content of the formulated product increased with increase content of the flavor. Minerals particularly $\mathrm{Mg}, \mathrm{Ca}, \mathrm{K}$ also increased in the addition of the juice. The absence of coliform showed no faecal contamination and the product was safe for consumption. Thus, the utilization of beetroot as a natural flavouring agent improved the nutritional and sensory properties of the product. Both the thermized and unthermized yoghurt lasted for about two months without spoilage. From the foregoing, there is need for further studies on other minerals (nitrites) and vitamins (vitamin A) of the beetroot flavoured with different proportion of beetroot juice. Also, more researches should be carried out on the thermization of the yoghurt.

\section{References}

[1] B.F. Davidson, Yoghurt making illustration, in: Biology and Chemistry, Clermont Science College, Batavia, 2003, pp.45-103.

[2] G.J.H. Grubben, O.A. Denton, Plant Resources of tropical Africa Z, in: Vegetables, P. ROTA foundation, Wageningen, Backhugs, Leiden, CTA, Wageningen, 2004.

[3] J.K. Thompson, Yield evaluation of beetroot varieties, Journal of Agricultural Technology 4 (2001) 5-9.

[4] P.O. Ado, Beetroot cultivation, Beetroot and Eggplant Newsletter 18 (1999) 21-24.

[5] Anon. Betanal label, in: 1996 Product Manual, Hoechst Schering Agr-Evo. Pty. Ltd., 2000, pp. 60-602.

[6] H. Rehman, J.O. Ali, Plant spacing and sowing time affect on yield in Turnip crop, Sarhad J. Agri 16 (2000) 575-577.

[7] N. Stephen [Online], http://www.stephennottingham.co.uk/beetroot.htm, 2004.

[8] J. Adam, Betine, University of Maryland Medical Centre [Online], 2002, http://www.umm.edu/altmed/conssuplements/betainecs. html.

[9] FAO Compositional analytical methods, In: Manual of Food Quality Control, Food and Agricultural Organization of the United Kingdom, Rome, 1985, pp. 204-220.

[10] P.R. Ashurst, Fruit juices, in: P.R. Ashurst (Ed.), Food Flavouring, Blackie Academic and Sons Ltd., London, 1994, pp. 87-114.

[11] H. Egan, R.S. Kirk, R. Sawyer, Pearson's Chemical Analysis of Food 8th ed., Churchill, Livingstone, London, 1981, pp. 48-50.

[12] AOAC official methods of analysis-association official analytical chemists, 18th ed., Washington DC, 2010.

[13] G.I. Onwuka, Food Analysis and Instrumentation: Theory and Practice, Naphtali print, Lagos, Nigeria, 2005, pp. 119-121.

[14] FAO compositional analytical methods, in: Manual of Food and Agricultural Organization of the United Kingdom. Rome, 1986, pp. 204-220.

[15] L.M. Prescott, J.P. Harley, O.A. Klein, Microbial nutrition, types of media, in: Microbiology 6th Ed., McGraw Hill Publishers, New York, 2005, pp. 95-105.

[16] D.A. Pearson, The Chemical Analysis of Foods, 7th ed. Churchill and Livingstone, Edinburgh, 1976, pp. 402-518.

[17] R.S. Kirk, R. Sawyer, Pearson's composition and analysis of foods, 8th ed., Longman group Ltd., London, 1991, pp. 24-28, 42-48.

[18] H. Oberman, Z. Libudzisz, Fermented milk, in: J.B. Brian (Ed.), Microbiology of Fermented Foods, Blackie Academic and Professional, Chapman and Hall Publishers, London, 1982, pp. 308-345.

[19] M.R. Adams, M.O. Moss, Fermented and microbial foods, in: Microbiology, The Royal Society Publishers, United Kingdom, 1995, pp. 252-302.

[20] B.D. Michael, A. John, A.P. David, Vitamin C: Its chemistry and biochemistry, Royal Society of Chemistry, Cambridge, 1991, pp. 80-81.

[21] McCance, Widdowson, The Composition of Foods: Summary Edition, Royal Society of Chemistry, Cambridge, Great Britain, 1992.

[22] Y. Hiroya, G. Isutomu, O.O. Shige, The nutritional and physiological value of fermented milks, in: Functions of Fermented Milk, Challenges for the Health Science, Elsevier Applied Science Publishers, London, 1992, pp. 345-567.

[23] R.C. Orakwue, Quality characteristics of some brands of probiotic yoghurt sold in Nsukka, A B. Sc. Thesis. 
Department Food Science and Technology, University of Nigeria, Nsukka, 2007.

[24] L.N. Anyanwu, Production and evaluation of yoghurt flavored with solar dried bush mango pulp (Irvingia gabonensis). A.B.Sc. Thesis, Department of Food Science and Technology, University of Nigeria,
Nsukka, 2008.

[25] I.E. Mbaeyi, N.E. Awaziem, Effect of fermentation and physico-chemical, sensory qualities and storage stability of locally produced yoghurt in Enugu Metropolis, in: Proceedings of the 21st Annual Conference/General Meeting, Oct. 22-25, 2007, pp. 228-229. 